Article

\title{
Instruments for Assessing Historical Built Environments in Emergency Contexts: Non-Destructive Techniques for Sustainable Recovery
}

\author{
Pierluigi De Berardinis ${ }^{1}$ (i) , Carla Bartolomucci ${ }^{2, *}$ (i) , Luisa Capannolo ${ }^{1}$, Mariangela De Vita ${ }^{2}$, \\ Eleonora Laurini ${ }^{1}$ and Chiara Marchionni ${ }^{1}$ \\ 1 DICEAA, Department of Civil, Construction-Architectural and Environmental Engineering, University of \\ L'Aquila, 67100 L'Aquila, Italy; pierluigi.deberardinis@univaq.it (P.D.B.); luisa.capannolo@yahoo.it (L.C.); \\ elelaurini@yahoo.it (E.L.); chiaramarchionni.23@hotmail.it (C.M.) \\ 2 National Research Council-Institute for Construction Technologies (CNR-ITC), 67100 L'Aquila, Italy; \\ ing.mariangeladevita@gmail.com \\ * Correspondence: carla.bartolomucci@itc.cnr.it; Tel.: +39-862-316669
}

Received: 30 November 2017; Accepted: 3 February 2018; Published: 7 February 2018

\begin{abstract}
This article looks at a knowledge-based approach to emergency situations caused by earthquakes or other natural disasters, and illustrates how a multidisciplinary approach enables the integration of technical requirements with those of a historical and cultural nature. The case study presented is the recovery of the ex-city hospital of L'Aquila, in Italy, which was hit by an earthquake in 2009. The integrated use of varying investigation methodologies allowed us to establish the effectiveness of a knowledge-based approach, and generated new ideas for the development of the structure and its strategic role within the city.
\end{abstract}

Keywords: architectural heritage; historic urban landscape; survey (UAV); documentation; interpretation

1. Introduction. Existing Knowledge for the Building Recovery Project Following the 2009 Earthquake in L'Aquila (IT)

There has been a great deal of work published in the field of engineering on the earthquake that hit L'Aquila (Italy) in 2009, ranging from articles on structural science and techniques [1-4] to architecture and restoration [5,6], as well as articles on energy and technological aspects [7]. In parallel, rigorous legislation has also been drawn up to regulate reconstruction, resulting in a standardized methodology for defining projects and establishing financial contributions for private individuals.

Whilst this methodology has allowed for the uniform distribution of funds for reconstruction, it does not appear to have taken into account the value of the built historical patrimony, which can only be established through an understanding and knowledge of the same. Currently, under this legislation, buildings that constitute the historic patrimony are stripped down to individual elements in order to identify significant features so that the appropriate financial contribution can be assigned. However, this means, in particular for non-listed buildings, that the constructive body as a whole is not taken into consideration nor its historical stratification. Consequently the value of the built patrimony as a whole is not recognized nor are measures being put in act to safeguard it [8]. In brief, during the emergency and successive reconstruction, the priority appears to be the recovery of the functionality of buildings, as if the historical built environment was simply a 'building patrimony' without taking into consideration the qualities that characterize it or, using Bordieu's term, the 'cultural capital' [9].

However, an awareness of the history of a built environment is essential, not only to establish its value but also to interpret damage correctly and its seismic vulnerability (according to the 
"awareness pathway" indicated in the "Guidelines to evaluate and reduce seismic risk to the cultural heritage") [10,11].

Decree n. 1/2013 (Decree of the Special Office for the Reconstruction of L'Aquila) mentions recovery and conservation of original materials, construction types and structural function, even hypothesizing the use of innovative materials, provided that they are compatible with the value of the building and last over time. However these are merely indications and are rarely taken into consideration during the project phase or the execution of work, as a result of a number of factors such as the tight deadlines imposed.

The management of the post-earthquake state of emergency is also an area for reflection; the priority is to ensure the static stability of buildings thus avoiding any further collapses. However, the elements that give the historical built environment its identity are often not taken into consideration during this phase. These elements have often been damaged as a result of the use of tie rods and shoring up procedures or have been removed during the emergency phase without any documentation, often stored in inadequate conditions or worse still abandoned and left to deteriorate. This has led to the degradation and loss of material elements such as historical fixtures, stucco and plasterwork removed indiscriminately but of vital importance to the history of the construction and conservation.

An additional, preliminary phase is therefore needed to document and research the history of the built environment. The results of this phase, subsequently converted into specific plans, could then be used by the USRA (the city of L'Aquila's Special Reconstruction Office) to ensure sustainable recovery and reconstruction. Currently, documentation relating to the history of a building is simply presented as an attachment to planning projects. However, a report on the historical context and value of a building should be compulsory prior to static analyses in the reconstruction process. Furthermore, the drawing up of detailed plans in this additional phase would assist the reconstruction process by establishing guidelines, identifying constraints and highlighting intervention strategies, as well as allowing for coherence across the board. The reconstruction phase would also benefit from flexibility: the possibility of updating planning during the reconstruction process as new information comes to light, for example, the discovery of new elements within the layers of the building envelope itself.

In other words, historical and archive investigations should come before attempting to safeguard the varying elements of a building, which might otherwise be compromised. Moreover these studies together with the use of non-invasive diagnostic techniques could be developed during design and construction phases as an underlying support for the whole design process. The emergency situation created in L'Aquila after the earthquake of 2009 is an ideal context in which "virtuous models" of reconstruction can be developed. This paper proposes such a model-a recovery project based on knowledge of a historical building that, like many other historical buildings damaged by the earthquake, had undergone significant work (structural, energy conserving and restoration) over time.

A case of a building complex damaged in the 2009 earthquake is now presented. The aim of the study was to base the recovery project on knowledge of the historical building and its urban context and thus identify values (historical/architectonic, urban, symbolic-identifying, social) to guide the project and ensure the compatibility of its new proposed use. It involved a rigorous phase of information acquisition of the building under study (the ex-city hospital) including historical, architectonic, technical and constructive analyses. The ex-city hospital had not been subject to the usual emergency measures taken to ensure safety such as scaffolding or props after the earthquake allowing a clear picture of the structure's walls.

This study was initially part of a degree thesis [12] and subsequently grew to incorporate studies in varying disciplines $[13,14]$, and thus it was possible to highlight, on the one hand, the current state of deterioration and on the other, to identify the features to safeguard and use for the basis of the new project. 


\section{The Influence of a Knowledge-Based Approach on Re-Qualification/Recovery Planning}

In-depth knowledge of a building is of inestimable value when the main aim of conservation is that of preserving its identity over time [15]. It is clear that recovery of a complex and its subsequent architectonic requalification will be complex, especially at this time when the historical architectonic patrimony is of such importance.

Specific and differing core competencies are required to acquire the in-depth knowledge needed to complete this task and therefore an interdisciplinary approach is needed.

An awareness of the construction history of a building is essential in assessing its current seismic safety and the most effective means of intervening. In fact, knowledge of the original characteristics of the construction, changes made over time, the state of the materials used as well as the effect of natural disasters, is fundamental. Recent legislation (the Decree of the President of Council of Ministers of 9 February 2011) has recognized this need and established procedures to be followed using varying sources on the basis of the depth of knowledge required.

The knowledge process is based on the study of the features of the building complex under different lights: historical-urban, historical-architectural, technical-constructive, materials and structural. These analyses, carried out in parallel, allow us to discover the history of the building, identify its significance and the features that need safeguarding as well as the technical and constructive aspects that characterize it and its state of degradation. All of these elements are fundamental in the drawing up of a project for recovery and restoration (Figure 1).

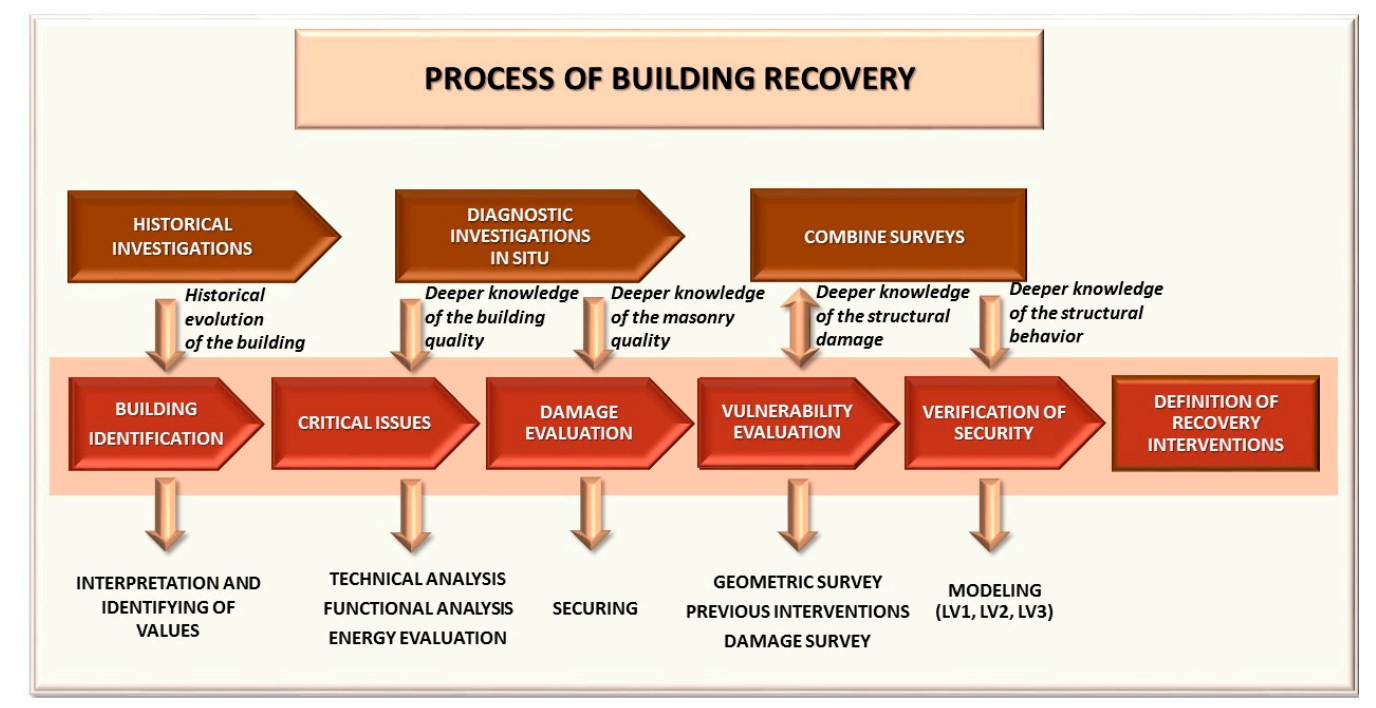

Figure 1. The methodological process and identification of the level of knowledge of a historical building. The multi-disciplinary approach is highlighted in brown and it is developed during design and construction phases as an underlying support for the whole design process.

The first step is a detailed analysis of the existing structure to establish building structure and to identify additions of little architectonic value, which can be removed to allow an overall vision and understanding of the historical construction.

Intervention in building in post emergency contexts also brings problems of its own: firstly, the difficulty of taking accurate measurements (which would facilitate the three dimensional reconstruction of the buildings and identification of their appurtenances) as a result of the dangerous conditions caused by the earthquake and, in this case, the general state of disrepair of the complex; secondly discovering how successive phases of building influenced the evolution of the building complex and lastly, in an age where saving resources and reducing energy consumption are essential, the absence of information on the building's thermal dispersion and consequently the thermal requirements [16]. 
However, a multidisciplinary approach using non-destructive diagnostic techniques has been shown to be most effective in overcoming these difficulties, most notably in the field of energy use. Indeed thermographic, thermo-hydrometric and thermal flux analyses have evolved rapidly as a result of recent developments in geomatic measurement techniques [17] including photogrammetric measurement with unmanned aerial vehicle (UAV) technology, and are used increasingly in the field of recovery of cultural heritage [18]. These devices are equipped with optical, thermal or multispectral sensors according to the use required, giving accurate and precise readings even over periods of time, in areas that are difficult to access or that might put ground operators in danger [19].

Non-destructive investigation techniques are ideal for use with historical or listed buildings borne out by international recognition of the relationship between sustainable recovery and non-destructive techniques $[20,21]$. Thermal imaging, for example, is a rapid, non-invasive technique that can be used to provide information concerning the historic building envelope [22], structural aspects such as cracks [23], and to monitor forms of degradation, caused, for example, by moisture or the presence of water [24]. By analyzing thermal imaging data, it is also possible to establish the differing thermal capacity of materials used in construction and therefore trace back transformations such as the sealing or opening up of different rooms, integrations, planning accretions or interventions subsequently covered up by further stratification [25]. It also sheds light on construction techniques [26].

The knowledge acquisition process provided the necessary information for the development of a project using a rigorous, multidisciplinary approach especially important when the historical and architectonic values of a building are not immediately evident.

Both investigations described above were therefore of great importance in the reconstruction of the constructive history of a building body and consequently for the recognition of the values to safeguard and highlight in the planning phase.

The multidisciplinary approach described here is the first stage of building recovery and is followed by interventions aimed at achieving functional recovery on the basis of the findings of preliminary stage in addition to improvements in energy efficiency and resistance to seismic activity. Non-destructive investigations can also be used for structural studies, identifying the different materials used [27-29]. For example, thermography allows the analysis of walls without the need to remove plastering or finishing that often merit conservation and is an excellent method for detecting the presence of different types of walls (built in different periods or with different techniques), reinforced concrete curbs on walls, discontinuous wall elements, and so on. This study therefore also highlights how this type of approach represents a tool for planning.

\section{The Case Study of the Ex San Salvatore Hospital in L'Aquila (IT)}

The building complex which made up the city of L'Aquila's ex hospital now belongs to the University of L'Aquila and is situated to the north of the city bordered by the city's walls (Figure 2) and delimited to the south, by Viale Duca degli Abruzzi, an important axis road along which the modern transformation of the city is evident.

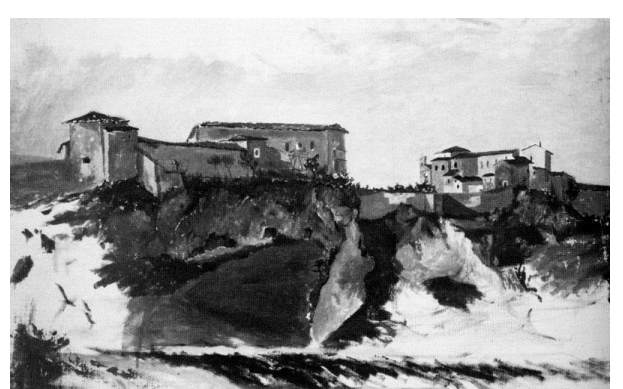

(a)

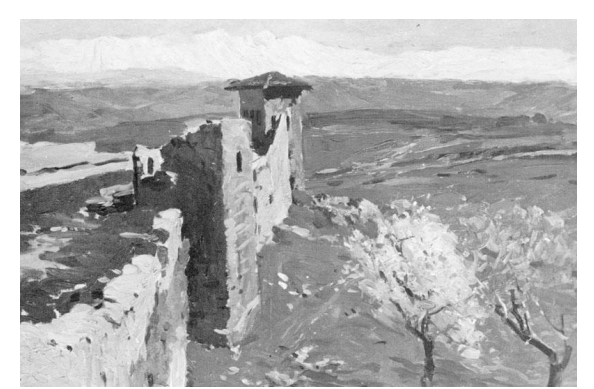

(b)

Figure 2. Paintings by D. Cifani: (a) View of the former hospital (1919); (b) View of the ancient walls (1930). 
The building complex, currently in a state of disrepair as a result of the earthquake and years of abandonment, had undergone numerous alterations over the years and its original structure has been all but lost as a result (Figure 3).

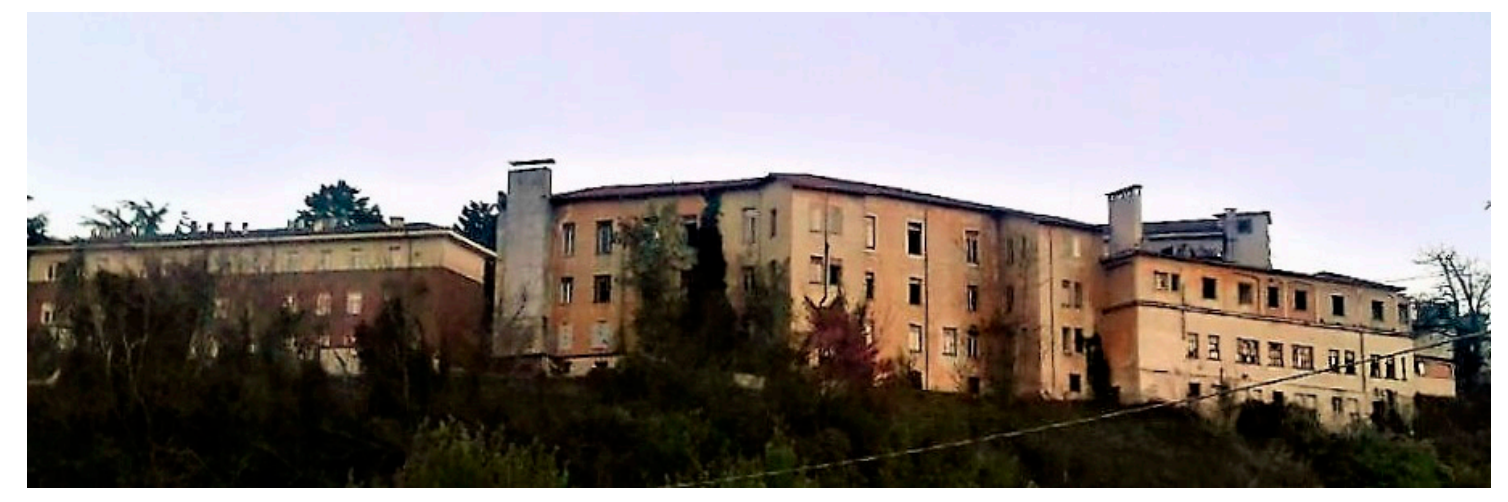

Figure 3. The north face of the former Hospital of S. Salvatore as it currently appears: view from outside the urban walls, L'Aquila.

Archive documents and site visits revealed how the hospital had changed since its foundation in 1875. Evidence also emerged of pre-existing structures on the site that were in part transformed and in part destroyed by the construction of the hospital but which constitute an important part of city's urban history and were used as a focus for the new project [30,31]. Indeed, the hospital stands on the site of an ex monastery that was abandoned after the Napoleonic suppression and several of its buildings were subsequently incorporated into the new hospital. The hospital was then extended with the construction of a new wing that, in turn, was subject to a series of changes during construction. It was initially proposed to preserve the pre-existing buildings, in particular the monumental church of Santa Maria del Guasto, and built to the rear. However, during construction, it was decided to double the size of the building and incorporate the church into the new structure. However, the church was subsequently demolished.

Historical documents from that time have shed light on some important elements such as the relationship of the building complex with walls of the city, planning changes, the demolition of the city walls during the construction of the hospital, access routes lost as a result of recent construction, the role of the structure as a meeting place and the existence of a square for recreation, lost as a result of further construction.

All of this information is considered vital for the recovery and development of the existing structure, and have become elements to develop and transmit with the building itself, considered a material document of the history of part of the city, as well as planning stimuli for the definition and design of new functions [14,32].

\subsection{Investigation of the Building Complex and Identification of Historical Construction Phases}

The former hospital of L'Aquila is made up of a collection of buildings, the majority of which were built during different phases in the 20th century, near the city walls to the north of the city. The first nucleus of the hospital was established in 1875, recovering pre-existing structures from the monastery of Saint Agnese (dating back to the 14th/15th century and abandoned in 1807). The buildings making up the monastery of Saint Agnese, its church and the church of Santa Maria del Guasto were adapted and altered over the years to meet changing needs.

After the earthquake in 1915, in which the hospital only received light damage, several structural improvements were made (reinforcement with metal tie rods, lintels, new ceilings in iron, demolition of ceilings in plaster). However, it was not until the 1930s that an overall renovation program was started. In 1931, the first plan to extend and renovate in fact appeared, proposing the demolition of 
external walls and the construction of a new wing behind the existing structure, which was mainly conserved (Figure 4). The plan was modified during the course of work, with additions and variations that saw the "radical transformation of the old part where only simple adaptations had been planned". The sequence of events is summarized in "Relazione svolgimento lavori" (on 25 April 1938) in the final accounting documents (Archivio di Stato di L'Aquila, Cat. X, f. 239). The work started on 20 January 1932 and ended on 25 February 1937. The most significant of these changes was the demolition of the church of Santa Maria del Guasto and a new section to make a single front section with access, doubling the size of the building around a central court (Cfr. "Perizia Suppletiva", 20 April 1933, f. 238).

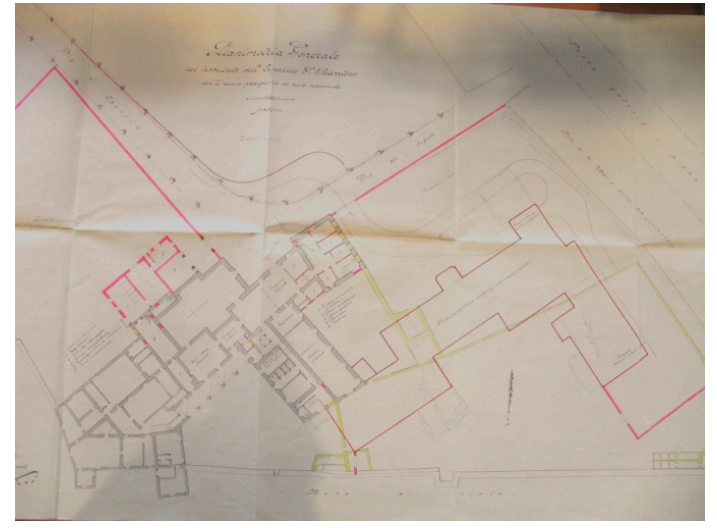

(a)

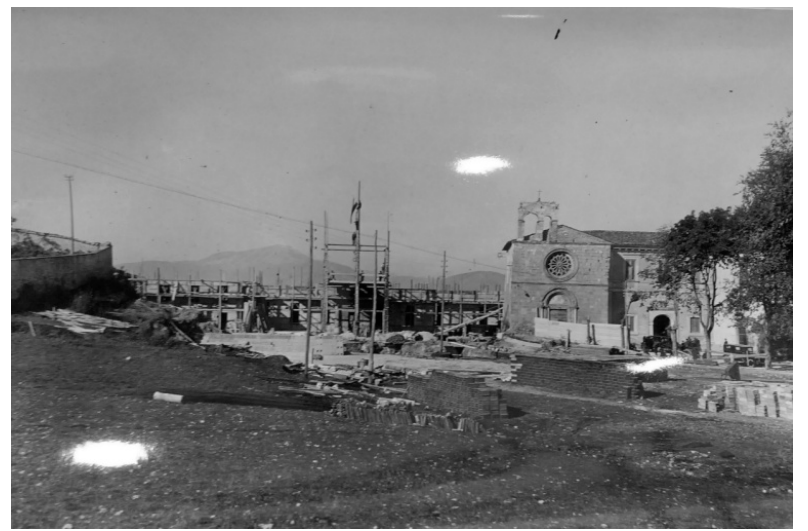

(b)

Figure 4. The expansion project of 1931: (a) The general plan of the first project/design hypothesis (Cfr. ASA, Comune Aq, cat. X, cl. II (1906-1940): Lavori al civico Ospedale di San Salvatore. Drawings highlighting the "old structures" and the new hospital plan with an explanatory report, 25 April 1931, Eng. R. Inverardi); (b) The construction yard.

In this case, as in many others, the motivation and reasons for the new construction were considered of more importance than the historical building itself (see also the demolition of the "Edificio delle Cancelle" in Piazza Duomo and other buildings of lesser note) [33]. This was despite the fact that, even then the value of the church had been recognized having been included in the official list of important buildings in the Province. However, the demolition of the front of the church was considered feasible, and subsequently the entire building, on the grounds that the facade could be rebuilt elsewhere.

In 1934, the construction of a new wing brought about the demolition of a significant part of the city's walls; the wing was built on the historical nucleus of an ex-convent and successive elevations have resulted in the wing having the same building size as the neighbouring building, which has nevertheless kept its original form reproducing exactly the planning of the wall with its two watchtowers.

Although building finished in 1937, by 1941 a new project had already appeared on the table, proposing to renovate the 'old' part of the building (the ex-monastery) and to construct a new wing. The project was realized a few years later (1947-1954) due to the war events. This new work, completed using the same method and materials as the original, with brick and stone, can only be distinguished now because of deterioration of the rendering on the eastern side. It is difficult on the other hand, to distinguish between the original building and the extensions on the other sides.

The hospital was extended substantially once again from 1961 to 1969 with the building of a further wing along the road Viale Duca degli Abruzzi, on the opposite side to the city walls. This, together with a new road transport system, increased the isolation of the hospital complex and reduced accessibility. The reconstruction of the building history of this complex is essential to be able to identify extensions, elevations and accretions which are difficult to recognize today given the state of disrepair that the 
complex has fallen into and successive wall renderings of the entire building. Above is a drawing highlighting the construction phases and the accretions to remove (Figure 5).

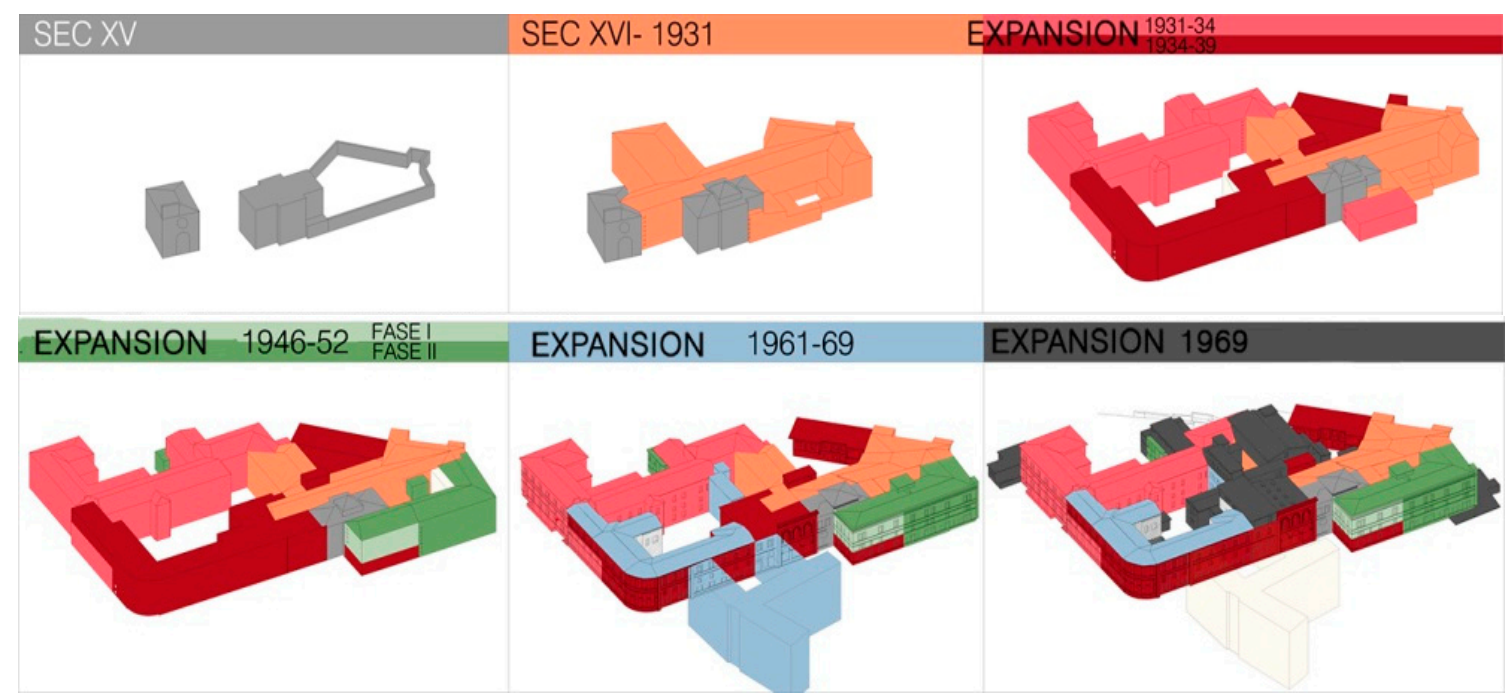

Figure 5. Axonometric view of the historical evolution of the former hospital complex [12].

\subsection{The Contribution of Non-Destructive Diagnostic Tools and UAV (Unmanned Aerial Vehicle) Surveys}

A reflection on the hospital complex in L'Aquila has highlighted how intervening on the building patrimony in post emergency contexts also brings problems of its own.

In order to overcome the obstacles mentioned in the methodology, non-destructive investigative techniques play an increasingly important role alongside historical research and site visits.

In the knowledge acquisition phase of this study, a multi-rotor Flynovex equipped with a Sony alpha 6000 camera was used in order to carry out an aerial survey. The choice of this type of UAV and equipment stems from other tests performed in different case studies in the post-earthquake period of L'Aquila in 2009 [34]. It has proved a good choice in terms of several technical aspects, in particular the payload of the camera and the stability of the vehicle during the acquisition phase (Figure 6).
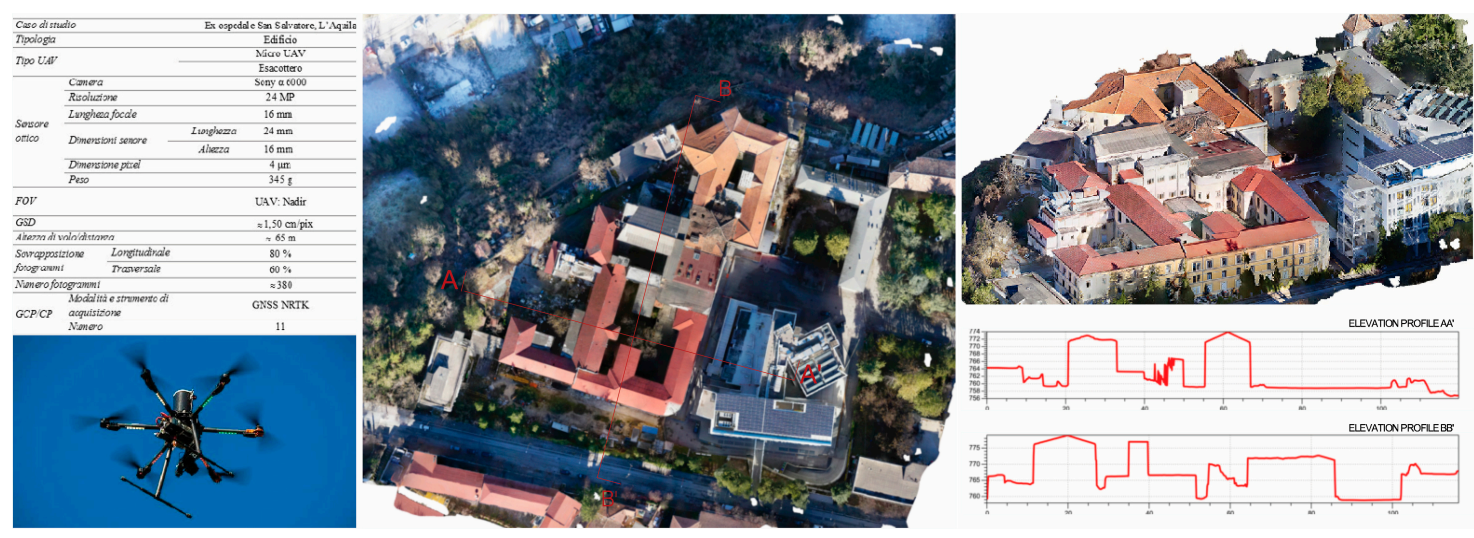

Figure 6. Unmanned aerial vehicle (UAV) photogrammetry. From left to right: features and views of the used vehicle; orthophotograph of roofing, three-dimensional reconstruction and elevation profiles obtained from the UAV campaign.

The data obtained allowed a visualisation of the whole complex, three dimensional, metric reconstructions, orthophotographs of roofing and facades, as well as altitude profiles. The results of the photogrammetric survey and the use of software allowed detailed research from the evaluation and 
quantification of damage to geomorphological analyses of the building, all required for sustainable requalification of the complex. The ability to assess roof coverings allowed us to complete the building survey and identify serious damage. Thanks to the use of GNSS-NRTK (Global Navigation Satellite System-Near Real Time Kinematic) techniques, the 3D model was georeferenced and can be inserted into a database allowing for the smart management of the territory.

The use of thermal imaging in this case highlighted elevated levels of thermal dispersion associated with wall coverings and proved useful in the identification of zones without heat bridges, which require further study to establish thermal transmission and therefore thermal requirements.

In addition, the use of thermal imaging under experimental conditions, varying the surface temperature [23], allowed the identification of different stratigraphs and construction techniques, in particular of the oldest part of the complex and surrounding buildings dating back to the 1950s. This section in fact was the most seriously damaged and will therefore be subject to significant interventions structurally, as well as in terms of energy saving (Figure 7) [35].
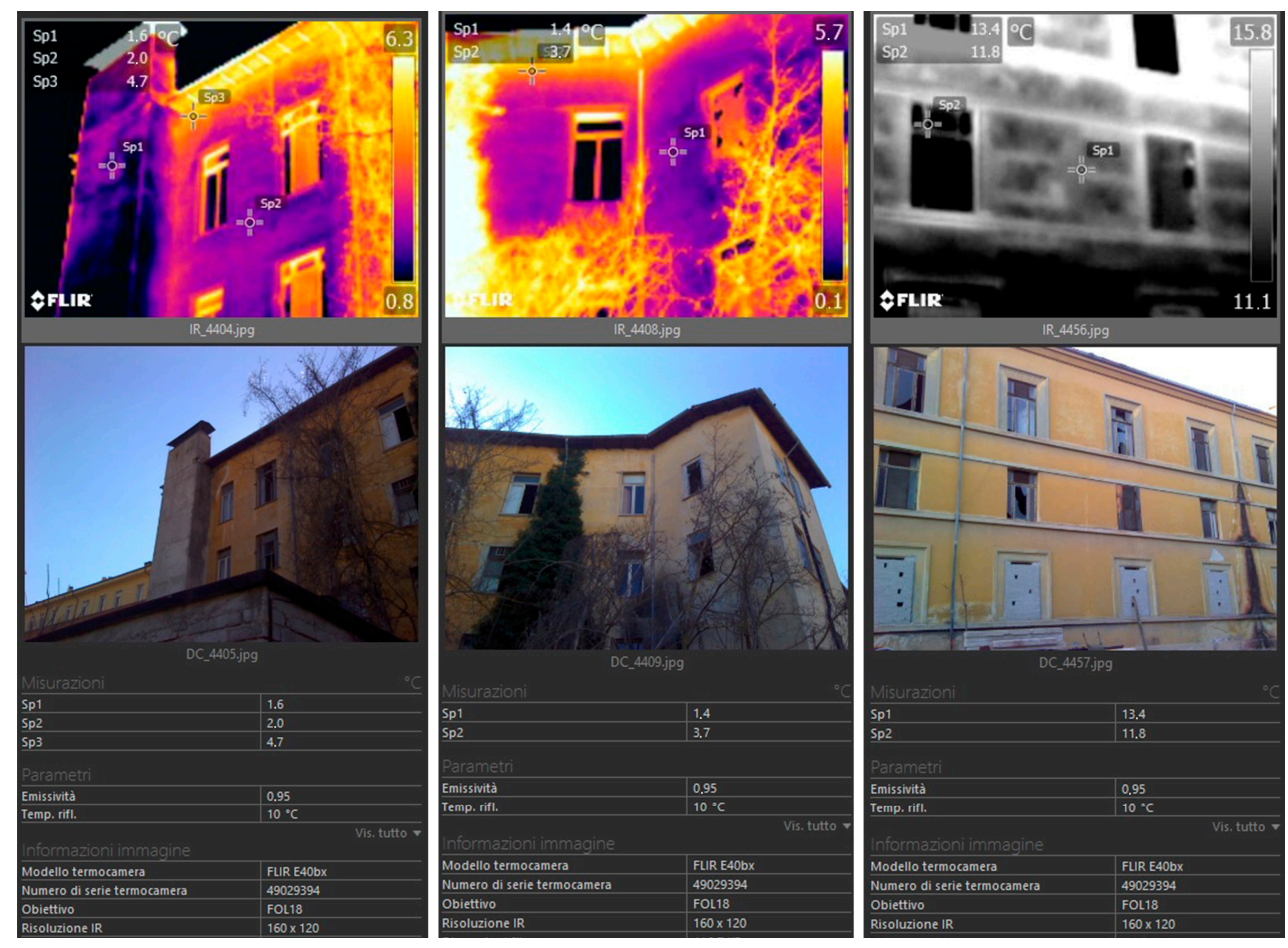

Figure 7. Thermographic survey: view of some elaborated thermal imaging data.

This investigation, based on surveys, historical research of cultural, geometrical and territorial aspects and the use of non-destructive diagnostics has produced extremely useful results that provide in depth knowledge concerning the patrimony under study and a guide for successive intervention of requalification.

\section{An Interpretative Summary of the Analyses Carried Out and Project Methodology Guidelines}

In the case of the former hospital, the knowledge acquisition process described proved invaluable in defining the methodology for the recovery project and for avoiding incongruous additions or interventions incompatible with the existing structures (Figure 8) [36].

Amongst the various analyses carried out, the three dimensional reconstruction of the building allowed an overall vision and definition of the formal and dimensional aspects, particular useful in gaining an understanding of the peculiarities of the complex. However it is important to point out that cross-checking of data acquired from historical and archival surveys with that of the three-dimensional studies was essential in the reconstruction of the history of this building complex and for confirming 
data obtained from aerial surveys. Indeed, the mere observation of the structures and roofing could have provided misleading results—-for example, contemporary roofs masking buildings constructed in different historical periods.

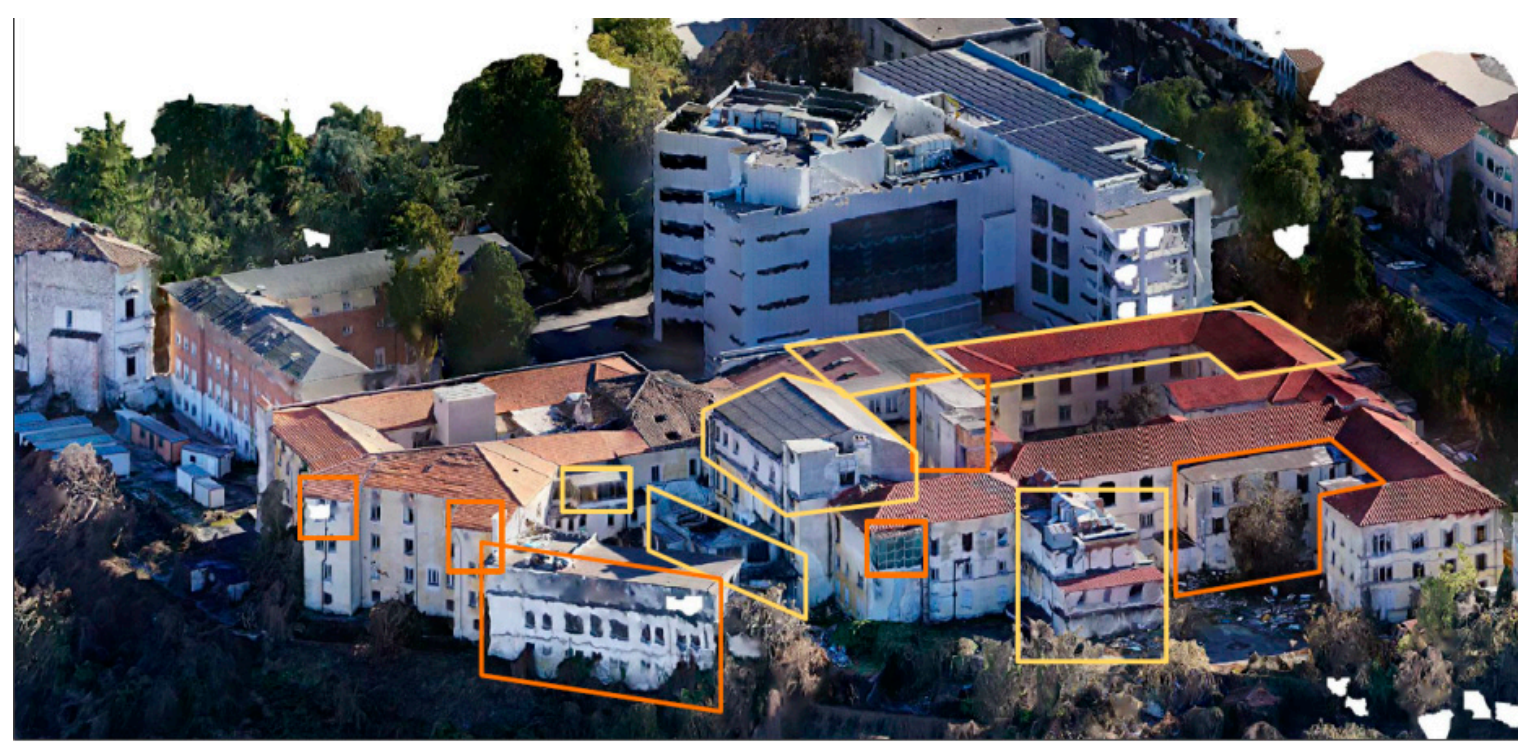

Figure 8. Identification of inadequate additions (yellow outlines) or design incongruity (orange outlines) that have to be demolished: the technologies used for the investigations allowed to carry out highly detailed studies on volumes, in order to accurately determine the configuration of the building for the project initial phase.

Thermal imaging, on the other hand, allowed us to ascertain the constructive apparatus of the building and to highlight discontinuities in materials which support documentation and hypotheses concerning the varying phases of transformation that the building underwent. They were also important for the recognition of cultural and architectonic values that are no longer evident, as well as incongruous elements that prevent a correct understanding of the building complex. A number of historical and typological features of the building were in fact hidden as a result of interventions over the years that erased traces of pre-existing structures, within the building as well as on an urban scale from sight. In addition to this architectonic clouding of the picture, years of disuse and degradation have contributed to deterioration of the state of conservation and its original material characteristics (Figure 9).

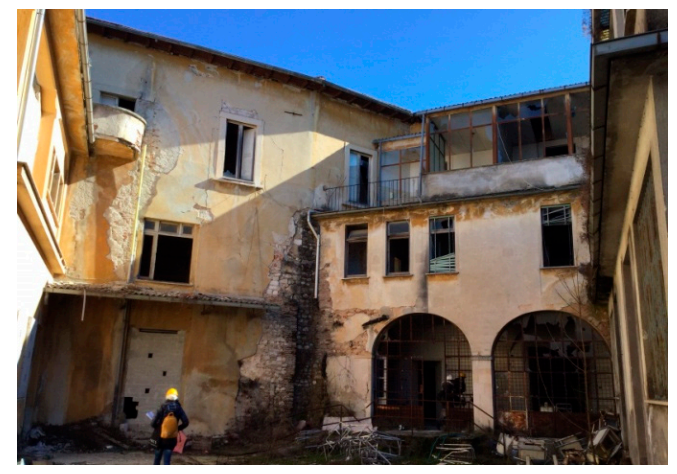

(a)

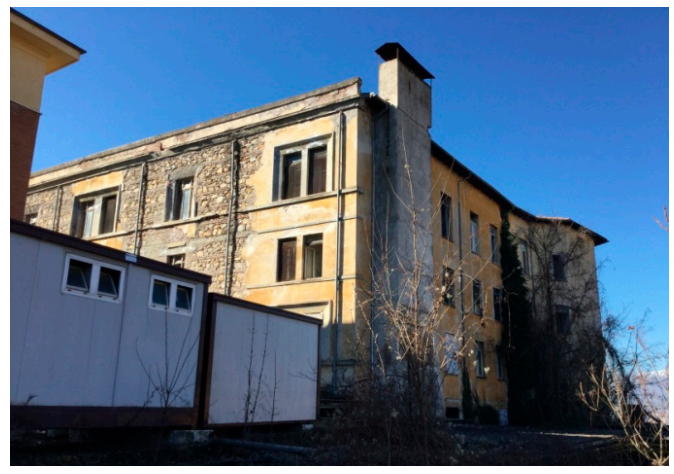

(b)

Figure 9. The current state of degradation observed in the inspection of 16 February 2016: (a) The court enclosed by inadequate extensions; (b) A view of the north face of the complex. 
Intervention on the existing structure must necessarily focus on traces lost over time, the site and its strategic relevance, as well as the historic value of the structure itself. Furthermore, on the basis of a careful compatibility analysis, it must also endeavor to enhance the typological characteristics established with the most recent extension of the building complex [14].

On an urban level, the ex-hospital structure is rather isolated, situated at the margins of the historical centre whilst also visible from the outskirts. Therefore the aim of the requalification project is to re-connect the complex with the city as well as to reconfigure its perception from beyond the city walls, fragmented over time by the presence of constructions and accretions. The strategy adopted to establish this link between the historical fabric of the city and the building itself involves transferring distinctive features of the urban fabric within the building fabric. This re-connection would ideally be achieved through new access to areas of intervention that retrace pre-existing ones through a widening of the pedestrian area along the road to the south and elevated with respect to the building.

On a building scale, the main objective is to safeguard all pre-existing structures of historical, architectonic or cultural value recognized as 'structural typological invariants' and symbolic re-evocations of those values lost such as the church of Santa Maria del Guasto [32]. Relocating evidence of the original project will require the demolition and removal of structures that, for varying reasons, were added to the original building over the years but are now considered incompatible. These additional works are in fact of no value and suffered significant damage as a result of the earthquake and have contributed to a deterioration of the microclimatic conditions of the building complex [12,13].

All of this information, which can initially appear disparate or contrasting in nature, must then come together in a single, coherent project for recovery that takes into account all of the aspects with balanced criteria. In a similar manner, the knowledge acquisition phase must come before the securing of the building; in fact this intervening period is the most appropriate time to intervene correctly to ensure the preservation of elements of value, as well as structural ones. These preliminary interventions represent the first stage of building recovery. Indeed, once the original site of the building has been identified, it is then possible to hypothesize the re-use of construction elements that were removed in the first stages to give life to new structural or decorative elements or to set aside for other functions, in the path of environmental sustainability and economy in the use of resources. In fact, the principles at the basis of sustainability are tied to resource economy and hence the conservation of materials as well as to the lifecycle of the project for the optimization of the quality of building processes [37].

Lastly, the insertion of new functions can only be achieved through carefully carried out compatibility studies especially on a spatial and dimensional level, adapting new uses to existing spaces or to new spaces according to the dimensional requisites of the use.

The building complex recovered in this way must be considered an example of compatible intervention on a structure of symbolic value for the city, an emblematic place that once was once dismissed but now aspires to promote and represent urban requalification rather than be dismissed once again as a mere functional structure [14].

\section{Conclusions}

A methodological project aimed at the state of the art recovery of a building of historical and architectonic value cannot ignore the importance of in-depth knowledge of the building itself. The knowledge acquisition phase consists of multiple investigations in an equally numerous number of fields.

The use of analytical instruments of varying nature, compatible for use with a building of value, is a professional practice that strives to bring to the light both the characteristics of the building and issues affecting it. These instruments can also shed new light on methodological approaches to adopt to gain a better understanding of the construction, highlighting the need for the planner to gain a full understanding of the characteristics of the place before intervening, with respect to the building's identity. 
Sustainability in building recovery can be assessed by looking at the compliance of material already in use with respect to the principles of sustainability and the drawing up of an energy budget that takes into account resources to be used and those already in use. Recovery interventions are, in fact, one of the most sustainable building processes, as they involve practices that will prolong the life of the building instead of leaving it to fall into a state of disrepair thus representing a saving in terms of energy, materials and the recycling of refuse. Even a change of use linked to current urban transformations can be sustainable as a new role can result in an improvement in performance from a technological point of view as well as in terms of consolidation and conservative rehabilitation. In conclusion and in a final analysis, all of these aspects influence the wellbeing of the end users and the two are closely intertwined; the aim of recovery is the re-utilization of spaces that have been abandoned or fallen into a state of disrepair, which in its turn leads to an improvement in the quality of life of those who live there, encouraging further recovery work.

A well-thought out planning process is essential for emergency contexts where buildings have been damaged by, for example, seismic activity; a planning process that includes surveys and analyses aimed at the acquisition of in-depth building knowledge in order to ensure effective and sustainable recovery. Unfortunately, this does not often happen, as post-earthquake legislation focuses on structural and mechanical investigations, while other preliminary investigations, recommended in official guidelines for seismic risk assessment, are often neglected. This study aims to be a starting point for the definition of best-practices for the reconstruction of cultural heritage, taking into account, implementing and adapting planning guidelines for the recovery of the built environment following catastrophic seismic activity.

Acknowledgments: The authors would like to thank the Spin-off of University of L'Aquila GITAIS srl for their assistance with the images acquired by UAV photogrammetric survey, in particular Prof. Donatella Dominici, Ing. Maria Alicandro and APR Giuseppe Colagrande.

Author Contributions: Pierluigi De Berardinis has conceived, designed and supervised the research; Carla Bartolomucci conceived and performed the historical research, wrote Section 1 with Mariangela De Vita and Eleonora Laurini, wrote Sections 3 and 3.1 and supervised the whole paper; All the authors wrote Section 2; Chiara Marchionni wrote Section 3.2, performed the non-destructive surveys and designed Figures 6 and 7; Luisa Capannolo wrote Section 4, performed the historical surveys and designed Figures 5 and 8; Mariangela De Vita and Eleonora Laurini conceived the structure of the paper, wrote the conclusions and designed Figure 1.

Conflicts of Interest: The authors declare no conflict of interest.

\section{References}

1. Salvatori, A. Miglioramento sismico di edifici storici in muratura danneggiati da eventi sismici. Il caso di due aggregati storici in L'Aquila. In L'Ingegneria Sismica in Italia, Proceedings of the XVI ANIDIS International Congress, L'Aquila, Italy, 13-17 September 2015; ANIDIS (Italian National Association of Earthquake Engineering): L'Aquila, Italy, 2015; ISBN 978-8894-098563.

2. Cifani, G.; Colasacco, B.; Lemme, A.; Mignemi, A.; Miozzi, C.; Santoro, C. Sisma Abruzzo 2009-Beni architettonici, storico-artistici e miglioramento sismico. In L'Ingegneria sismica in Italia, Proceedings of the XVI ANIDIS International Congress, L'Aquila, Italy, 13-17 September 2015; ANIDIS (Italian National Association of Earthquake Engineering): L'Aquila, Italy, 2015; ISBN 978-8894-098563.

3. Galeota, D.; Fanale, L.; Tohme, D.; Romagnoli, A.; Paone, A. Il progetto di miglioramento sismico dell'ex Convento di San Basilio danneggiato dal sisma del 2009. In L'Ingegneria sismica in Italia, Proceedings of the XVI ANIDIS International Congress, L'Aquila, Italy, 13-17 September 2015; ANIDIS (Italian National Association of Earthquake Engineering): L'Aquila, Italy, 2015; ISBN 978-8894-098563.

4. Artioli, G.; Casarin, F.; Benetta, M.D.; Da Porto, F.; Secco, M.; Valluzzi, M.R. Restoration of historic masonry structures damaged by the 2009 Abruzzo earthquake through injection grouts. In Proceedings of the 9th Australasian Masonry Conference, Queenstown, New Zealand, 15-18 February 2011.

5. Milano, L.; Morisi, C.; Calderini, C.; Donatelli, A. (Eds.) L'Università e la Ricerca per l'Abruzzo: Il Patrimonio Culturale dopo il Terremoto del 6 Aprile 2009; Textus: L'Aquila, Italy, 2012; ISBN 978-88-87132-80-9. 
6. Pace, V. Il terremoto del 6 aprile 2009 in Abruzzo: Danni, interventi, iniziative e schede. Kunstchronik 2010, 63, 45-96.

7. Forlani, M.C. L'Università per il Terremoto. Castelnuovo e L'altopiano di Navelli; Alinea Editore: Firenze, Italy, 2009; ISBN 8860554446.

8. Bartolomucci, C. La ricerca nel restauro come risposta al disastro. Il terremoto in Abruzzo: Priorità, prospettive, sfide e occasioni (sinora) mancate. In Ricerca/Restauro, Proceedings of the $1^{\circ}$ Convegno Nazionale della Società Italiana per il Restauro dell'Architettura, Roma, Italy, 26-27 Settembre 2016; Quasar: Roma, Italy, 2017; Volume 3A, pp. 705-715.

9. Bordieu, P. Le capital social. Notes provisoire. Actes Rech. Sci. Soc. 1980, 31, 2-3.

10. Donatelli, A. Conservation and structural safety in seismic zone: First considerations about post-earthquake restorations made in L'Aquila (Italy). In REUSO 2015, Proceedings of the III Congreso Internacional Sobre Documentación, Conservación y Reutilización del Patrimonio Arquitectónico y Paisajistico, Valencia, Spain, 22-24 October 2015; Editorial de la Universitat Politecnica de Valencia: València, Spain, 2015; pp. 481-489, ISBN 978-84-9048-386-2.

11. Donatelli, A. La ricerca nel restauro strutturale. Sicurezza sismica e consapevolezza storico-costruttiva: Il nodo cultural della recente normativa. In Ricerca/Restauro, Proceedings of the $1^{\circ}$ Convegno Nazionale della Società Italiana per il Restauro dell' Architettura, Roma, Italy, 26-27 September 2016; Quasar: Roma, Italy, 2017; Volume 3B, pp. 793-803, ISBN 978-88-7140-764-7.

12. Capannolo, L. Piano Strategico di Sviluppo Dell'università degli Studi dell'Aquila: Riqualificazione Energetica Sostenibile dell'ex Ospedale San Salvatore a L'Aquila. Master's Thesis in Engineering and Architecture (Supervisor Prof. P. De Berardinis), Università degli Studi dell'Aquila, L'Aquila, Italy, 2014.

13. De Berardinis, P.; Capannolo, L.; Marchionni, C. Sustainable and energy efficient rehabilitation of the former hospital of San Salvatore in L'Aquila. In Structural Studies, Repairs and Maintenance of Heritage Architecture XIV, Proceedings of the STREMAH 2015, A Coruna, Spain, 13-15 July 2015; Brebbia, C.A., Hernández, S., Eds.; Volume 153 of WIT Transactions on the Built Environment; WIT Press: Southampton, UK; Boston, MA, USA, 2015; pp. 171-182.

14. Bartolomucci, C. Il complesso dell'ex-ospedale San Salvatore a L'Aquila: Il contributo del restauro per il progetto di un nuovo polo universitario. In Le Nuove Frontiere del Restauro: Trasferimenti, Contaminazioni, Ibridazioni, Proceedings of the "Scienza e Beni Culturali" 33th International Congress, Bressanone, Italy, 27-30 June 2017; Edizioni Arcadia Ricerche: Marghera-Venezia, Italy, 2017; pp. 559-572, ISBN 978-88-95409-21-4.

15. Bevilacqua, S. Diagnostica e Conoscenza dei Beni Architettonici e Culturali. La Metodologia Applicata a un caso Studio Reale: La Cappella S. Rocco-Nichelino (TO); Edizioni Accademiche Italiane: Torino, Italy, 2014; ISBN 978-3639780994.

16. Lucchi, E.; Pracchi, V. Efficienza Energetica e Patrimonio Costruito: La Sfida del Miglioramento delle Prestazioni Nell'edilizia Storica; Maggioli Editore: Milano, Italy, 2013; ISBN 978-88-387-6260-4.

17. Davoli, P. Il Recupero Energetico Ambientale del Costruito; Maggioli Editore: Sant'Arcangelo di Romagna (RN), Italy, 2010; pp. 175-181, ISBN 9788838757563.

18. Stylianidis, E.; Remondino, F. Geomatics for Cultural Heritage Preservation. Available online: https:/ / www. gim-international.com/content/article/geomaticsfor-cultural-heritage-preservation (accessed on 1 July 2017).

19. Dominici, D.; Alicandro, M.; Rosciano, E.; Massimi, V. Multiscale documentation and monitoring of L'Aquila historical centre using UAV photogrammetry. In The International Archives of the Photogrammetry, Remote Sensing and Spatial Information Sciences, Proceedings of the GEOMATIC E RESTORATION Conference, Florence, Italy, 22-24 May 2017; Elsevier: Florence, Italy, 2017; pp. 365-371.

20. Dukanovic, D. Dialog between contemporary perspectives and conservation principles. In Rehab 2017, Proceedings of the 3rd International Conference on Preservation, Maintenance and Rehabilitation of Historical Buildings and Structures, Braga, Portugal, 14-16 June 2017; Amoeda, R., Lira, S., Pinheiro, C., Eds.; Green Lines Institute for Sustainable Development: Barcelos, Portugal, 2017; pp. 243-253, ISBN 978-989-8734-24-2.

21. Ascione, F.; Bianco, N.; De Masi, R.F.; De Rossi, F.; Vanoli, G.P. Energy retrofit of an educational building in the ancient center of Benevento. Feasibility study of energy savings and respect of the historical value. Energy Build. 2015, 95, 172-183. [CrossRef]

22. Roche, G. La Termografia per L'edilizia e L'industria; Maggioli Editore: Sant'Arcangelo di Romagna (RN), Italy, 2012; ISBN 978-8838768873. 
23. Maierhofer, C.; Krankenhagen, R.; Myrach, P.; Meinhardt, J.; Kalisch, U.; Hennen, C.; Mecke, R.; Seidl, T.; Schiller, M. Monitoring of Cracks in Historic Concrete Structures Using Optical, Thermal and Acoustical Methods. In Built Heritage: Monitoring Conservation Management; Toniolo, L., Boriani, M., Guidi, G., Eds.; Springer: Cham, Switzerland, 2016; pp. 93-102, ISBN 978-3-319-08532-6.

24. Proietti, N.; Capitani, D.; Di Tullio, V.; Olmi, R.; Priori, S.; Riminesi, C.; Sansonetti, A.; Tasso, F.; Rosina, E. MOdihMA at Sforza Castle in Milano: Innovative Techniques for MOisture Detection in Historical Masonry. In Built Heritage: Monitoring Conservation Management; Toniolo, L., Boriani, M., Guidi, G., Eds.; Springer: Cham, Switzerland, 2016; pp. 93-102, ISBN 978-3-319-08532-6.

25. Balaras, C.A.; Argiriou, A.A. Infrared thermography for building diagnostics. Energy Build. 2002, 34, 171-183. [CrossRef]

26. Bianco, A.; Esposito, A.; Tuzza, S. Le indagini non distruttive come strumento investigativo per la conoscenza delle tecniche costruttive dell'edilizia storica del ‘900: Il caso-studio di Reggio Calabria. In Proceedings of the X Conferenza Nazionale Sulle Prove Non Distruttive, Monitoraggio e Diagnostica, Milano, Italy, 11-13 October 2007; DEI: Roma, Italy, 2007; pp. 185-193.

27. Binda, L.; Cardani, G.; Saisi, A.; Calluzzi, M.R. Vulnerability analysis of the historical buildings in seismic area by a multilevel approach. Asian J. Civ. Eng. 2006, 7, 343-357.

28. Casapulla, C.; Argiento, L.U.; Maione, A. Seismic safety assessment of a masonry building according to Italian Guidelines on Cultural Heritage: Simplified mechanical-based approach and pushover analysis. Bull. Earthq. Eng. 2017. [CrossRef]

29. Lagomarsino, S.; Cattari, S. PERPETUATE Guidelines for seismic performance-based assessment of cultural heritage masonry structures. Bull. Earthq. Eng. 2015, 13, 13-47. [CrossRef]

30. Centofanti, M.; Brusaporci, S. Il disegno della città e le sue trasformazioni. Città Storia 2011, 1, 151-188.

31. United Nations Educational, Scientific and Cultural Organization (UNESCO). Recomendation on the Historic Urban Landscape; UNESCO: Paris, France, 2011.

32. De Berardinis, P.; Bartolomucci, C.; Giancola, F.; Capannolo, L.; De Vita, M.; Laurini, E.; Marchionni, C. Studio di Fattibilità per il Progetto di un Polo Universitario Nell'ex Ospedale San Salvatore; Università degli Studi dell'Aquila: L'Aquila, Italy, 2017.

33. Bartolomucci, C. Gli effetti del terremoto del 1915 nella città di Aquila: I danni e gli orientamenti per il restauro. In Avezzano, la Marsica e il Circondario a Cento Anni dal Sisma del 1915. Città e Territori tra Cancellazione e Reinvenzione; Ciranna, S., Montuori, P., Eds.; Consiglio Regionale dell'Abruzzo: L'Aquila, Italy, 2015; pp. 151-233, ISBN 978-88-94083-40-8.

34. Dominici, D.; Alicandro, M.; Massimi, V. UAV photogrammetry in the postearthquake scenario: Case studies in L'Aquila. Geomat. Nat. Hazards Risk 2016. [CrossRef]

35. De Berardinis, P.; Rotilio, M.; Capannolo, L. Energy and sustainable strategies in the renovation of existing buildings: An Italian case study. Sustainability 2017, 9, 1472. [CrossRef]

36. Lanzarone, F.; Gargagliano, L.; Cuffaro, M.C. Progettare il Recupero Edilizio; Dario Flaccovio Editore: Palermo, Italy, 2010; ISBN 978-88-579-0061-2.

37. Balzani, M.; Marzot, N. Architetture per un Territorio Sostenibile. Città e Paesaggio tra Innovazione Tecnologica e Tradizione; Skira Editore: Milano, Italy, 2010; ISBN 885720737.

(C) 2018 by the authors. Licensee MDPI, Basel, Switzerland. This article is an open access article distributed under the terms and conditions of the Creative Commons Attribution (CC BY) license (http://creativecommons.org/licenses/by/4.0/). 